\title{
Epidemiological and Genetic Characteristics of the H3 Subtype Avian Influenza Viruses in China
}

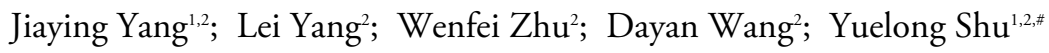

Avian influenza viruses (AIVs) are naturally preserved in waterfowls and sometimes spill over to infect humans and mammalian animals. The $\mathrm{H} 3$ subtype is one of the most prevalent influenza virus subtypes in waterfowls. Since 2000, H3 subtype AIVs have been continuously isolated from poultry and wild birds in the mainland of China, which implied a dynamic spread in large-scale geography and multiple species. Combinations of $\mathrm{H} 3$ with $\mathrm{N} 1-\mathrm{N} 8$ subtypes were reported, among which $\mathrm{H} 3 \mathrm{~N} 2$ and $\mathrm{H} 3 \mathrm{~N} 8$ subtypes predominated. Frequent mutations and reassortments increased the genetic diversity associated with altered virus virulence, transmission, and mammalian adaptation of $\mathrm{H} 3 \mathrm{AIVs}$, posing a potential threat to animal and human health. This study systematically analyzed the epidemiology, genetic characteristics, and mammalian adaptation-related mutations of $\mathrm{H} 3$ subtype AIVs in the mainland of China, facilitating the $\mathrm{H} 3$ subtype AIVs research and risk assessment.

Avian influenza virus (AIV) belongs to the Orthomyxoviridae family Influenza virus $A$ genus, packaged with 8 negative-sense and single-strand RNA segments, which encode a total of 14 proteins (1). Based on the antigenic diversity of surface glycoproteins hemagglutinin (HA) and neuraminidase (NA), AIV can be classified into 16 HA subtypes (H1-H16) and 9 NA subtypes (N1-N9) (2-3). Except for the $\mathrm{H} 17 \mathrm{~N} 10$ and $\mathrm{H} 18 \mathrm{~N} 11$ subtypes found in bats in recent years, all other subtypes of influenza $A$ virus can be found in wild waterfowls. Therefore, wild waterfowls are known as the natural reservoir and gene pool of influenza A virus, and AIV is considered to be the source of other animal influenza viruses (4). According to the pathogenicity of AIV to chickens, it can be divided into highly pathogenic AIV (HPAIV) and lowly pathogenic AIV (LPAIV) (5). Most avian influenza viruses exhibit low pathogenicity. To date, only partial proportions of $\mathrm{H} 5$ and $\mathrm{H} 7$ subtype AIVs have developed high pathogenicity, causing high mortality in wild birds, poultry, and even humans.

Among influenza A virus subtypes, the $\mathrm{H} 3$ subtype has a wide range of hosts. In addition to circulating in wild birds and poultry, it can infect multiple species of mammals such as humans, pigs, dogs, cats, horses, and even seals (6). The H3 subtype AIV is LPAIV and one of the influenza virus subtypes with the highest isolation rate among ducks (proportion up to $91.76 \%$ ) (7). Surveillance data showed that the $\mathrm{H} 3$ subtype AIV was widely prevalent in domestic ducks in the live poultry markets (LPMs) in China and reassortants were continuously being detected (8-9). Genetically, the HA genes of $\mathrm{H} 3$ subtype AIVs could be divided into Eurasian and North American lineages. Both H3 lineages were able to cross the species barrier to infect swine, while Eurasian lineage was identified to infect a wider range of hosts (swine, equine, canine, and human) than North American lineage (swine and seals) (10). In China, only the Eurasian lineage has been detected in domestic poultry (11). The interspecies transmissibility of $\mathrm{H} 3$ AIVs historically caused the H3N2 influenza pandemic in 1968 (12), which has posed a threat to human health (13).

Here, we systematically reviewed the current situation of the $\mathrm{H} 3$ subtype AIVs in China using surveillance data from 82 published studies and summarized the epidemiological and genetic characteristics and the mammalian adaptation of $\mathrm{H} 3$ AIVs in the first 20 years of 21 st century in the mainland of China.

\section{EPIDEMIOLOGY OF H3 AIVS IN CHINA}

Since the 1970s, China has reported isolation of AIVs (14). After Hong Kong Special Administrative Region (SAR) reported 18 human infections and 6 deaths caused by HPAIV (H5N1) in 1997 (15), avian influenza surveillance has received global attention for pandemic preparedness. During 2000-2019, AIV surveillance had been conducted in LPMs, poultry farms, and wild birds habitats in the mainland of China. Extensive and continuous active surveillance work included collecting throat and cloacal samples from birds and bird-related environmental specimens 
such as feces, water, and cage surfaces (11,16-21). Since 2009, surveillance has been intensified in all of 31 provincial-level administrative divisions (PLADs), with a sampling frequency from $2-4$ weeks a time to once a year. H3 AIVs were subtyped by RT-PCR or sequencing directly from the samples or AIV isolates.

$\mathrm{H} 3$ combinations with multiple NA (N1-N8) subtypes were detected in the mainland of China, dynamically circulating in poultry and wild birds, usually with no apparent illness (22). $\mathrm{H} 3 \mathrm{Nx}$ could affect domestic ducks, chickens, geese, pigeons, and quails and mainly circulated in LPMs in China (23-25). From January 2000 to June 2021, 50 studies have reported the detection of $\mathrm{H} 3$ subtype AIVs in domestic ducks, including $6 \mathrm{H} 3$ subtype AIVs such as H3N1, H3N2, H3N3, H3N6, H3N7, and H3N8. Overall, 23 articles reported the prevalence of $\mathrm{H} 3$ subtype AIVs in domestic chickens. Furthermore, 8 subtypes, H3 combined with N1-N8, have circulated in wild birds, and $\mathrm{H} 3 \mathrm{~N} 8$ was predominant, with a higher prevalence rate in Anseriformes (20-27). A 4year surveillance study (2015-2019), including more than 28,000 samples of wild birds from the QinghaiTibet plateau, found that H3N8 was the most abundantly detected $\mathrm{H} 3$ virus subtype (20).

To summarize the activities of $\mathrm{H} 3$ AIVs in the mainland of China, we have counted each $\mathrm{H} 3 \mathrm{Nx}$ subtype at the provincial scale each year. For example, if one or more studies reported that H3N2 AIV was found in Heilongjiang Province in 2010, it would be an activity of H3N2 AIV. Since 2000, 214 activities of H3 AIVs have been detected in 26 PLADs in the mainland of China except for the PLADs of Xizang (Tibet), Gansu, Shaanxi, Shanxi, and Hainan (Figure 1A). Surveillance indicated that H3 viruses have become enzootic in domestic ducks in southern China*, where LPMs bring together numerous host species in a high-density setting, creating an ideal environment for viral reassortment and interspecies transmission (23). In eastern $\mathrm{China}^{\dagger}$ and northeastern China ${ }^{\S}$, H3 AIVs could affect both domestic poultry and wild birds, except for Fujian, Shandong and Zhejiang provinces where $\mathrm{H} 3$ viruses were only detected in domestic poultry (Figure 1A). Previous studies have reported that $\mathrm{H} 3 \mathrm{~N} 8$ circulated in the Poyang Lake area around Jiangxi Province (18) and the wetlands of Jiangsu Province (28), which are along the wild fowl migratory flyway. In northeastern China, H3 AIVs with multiple NA subtypes (including N2-N8) were detected in wild birds in Heilongjiang Province (Figure 1A), where the complicated bird migration network lies (29). Researchers have continuously detected novel H3N8 subtype AIVs in wild ducks in their habitats such as the Heilongiiang Sanjiang Nature Reserve (30). H3 subtype AIVs were mainly detected in wild birds in northwestern China ", while in southwestern China* ${ }^{* *}$ they were mainly found in domestic poultry (Figure 1A).

In the last decade, increased detection of $\mathrm{H} 3 \mathrm{AIVs}$ was reported throughout the country. Notably, H3N2 and $\mathrm{H} 3 \mathrm{~N} 8$ have been consistently detected (Figure 1B). An epidemiological survey showed that poultry infection with H3N2 AIV occurred throughout the year in southern China, with higher detection rates in winter and spring and a lower detection rate in summer (31). In the wetlands of northeastern China, virus isolation rate of $\mathrm{H} 3$ subtype AIVs varied among seasons, and the highest rate was in autumn, which might due to the migration of wild birds (32).

In summary, H3N2 subtype AIV was the main prevalent subtype in poultry farms and LPMs from China, while $\mathrm{H} 3 \mathrm{~N} 8$ subtype AIV was widespread among wild birds in this region. Therefore, the following focuses on the H3N2 subtype and H3N8 subtype AIVs.

\section{GENETIC EVOLUTION OF H3 AIVS IN CHINA}

\section{H3N2 Subtype AIV}

Phylogenetic analysis showed that all of the H3N2 subtype AIVs in China belonged to the Eurasian lineage (11). The HA gene may be derived from viruses circulating in different regions of China and neighbouring countries in East and Southeast Asia $(7,17,33)$, while the NA gene may be derived from other AIVs such as H5 (34-35), H7 (9,36), H9 (23,36), and H11 (34) subtype AIVs in birds in East and Southeast Asia. The prevalence of H3N2 AIVs in birds and frequent reassortments with other AIVs also led to the emergence of various genotypes. Most of the

\footnotetext{
* Including Guangdong Province and Guangxi Zhuang Autonomous Region.

${ }^{\dagger}$ Including Anhui Province, Jiangsu Province, Jiangxi Province, Fujian Province, Shandong Province, Zhejiang Province, and Shanghai Municipality.

$\S$ Including Heilongjiang Province, Jilin Province and Liaoning Province.

"Including Qinghai Province, Ningxia Hui Autonomous Region, and Xinjiang Uygur Autonomous Region.

** Including Sichuan Province and Chongqing Municipality.
} 


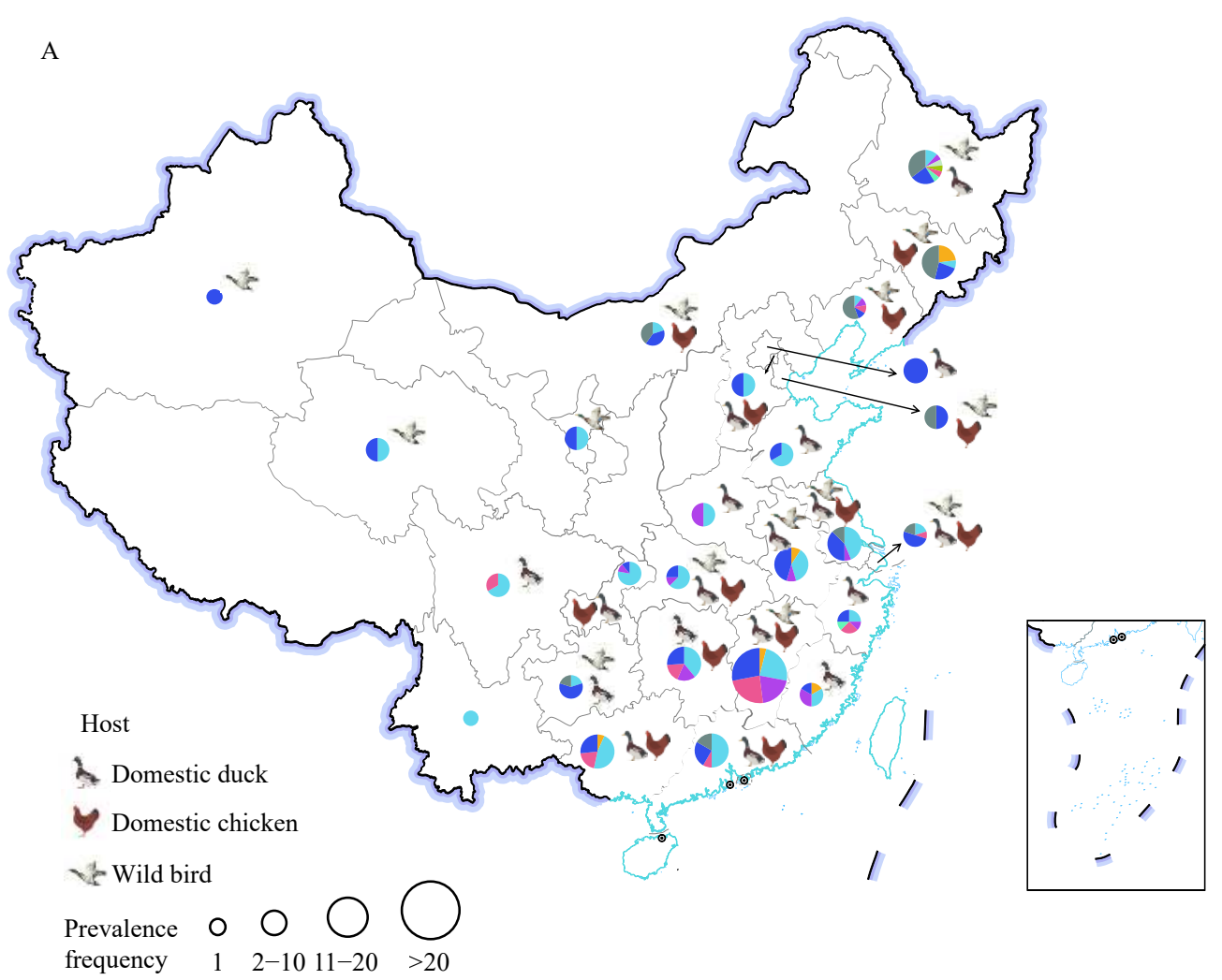

B

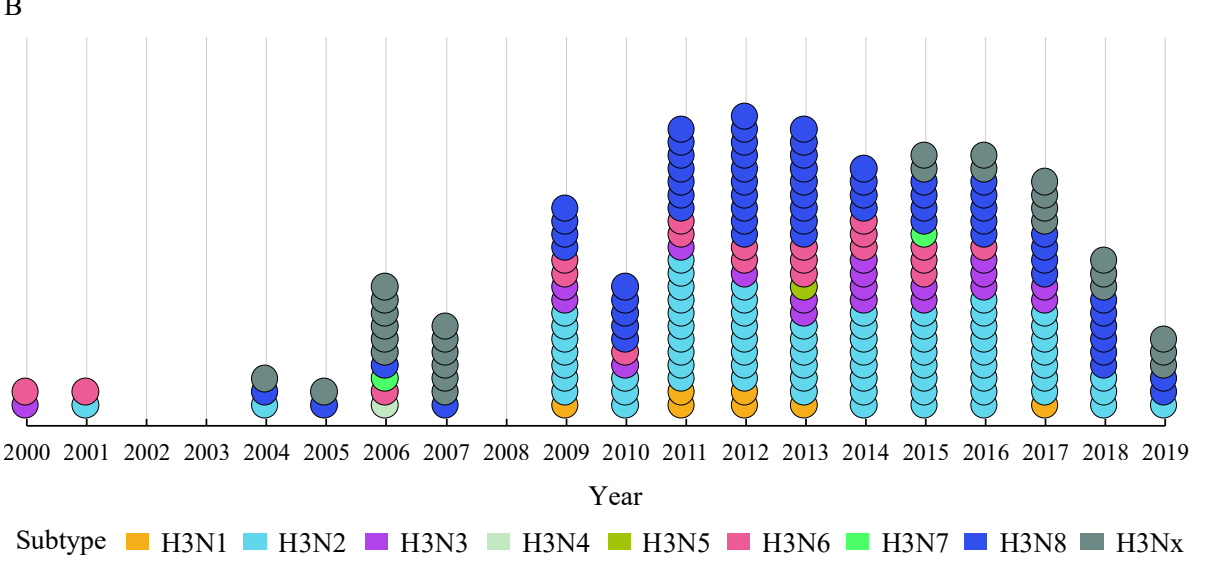

FIGURE 1. The spatiotemporal distribution and bird species of $\mathrm{H} 3$ subtype avian influenza viruses (AIVs) reported in the mainland of China from 2000 to 2019. (A) The spatial distribution and bird species of H3 subtype AIVs. (B) The temporal distribution of $\mathrm{H} 3$ subtype AIVs (according to collection year).

Note: As of June 6, 2021, 214 activities* of H3 subtype AIV have been counted in 26 provincial-level administrative divisions (PLADs) in China since 2000. Each H3Nx subtype is shown as specific color. The diameter of the pie chart (A) represents the number of H3Nx subtype AIV activities. Each circle in (B) represents an activity. Data were accessed from 82 published literatures on PubMed, CNKI, and Wanfang databases, searched up to June 6, 2021.

* Each $\mathrm{H} 3 \mathrm{Nx}$ subtype at the provincial scale each year has been counted. For example, if one or more studies reported that H3N2 AIV was found in Heilongjiang Province in 2010, it would be an activity of H3N2 AIV.

reassortants came from LPMs along the bird migration routes, which suggests that wild bird migration might have a great impact on poultry AIV infection $(8,18,23,37)$. Studies have found that the PA gene of H3N2 subtype AIV of Chinese ducks was highly homologous to the HPAIV H7N9 in Korean wild ducks (33). The H9N2 viruses that were prevalent in poultry in eastern China [Jiangxi (23), Jiangsu (38), Zhejiang (39)] also provided internal genes for $\mathrm{H} 3 \mathrm{~N} 2$ AIVs. The internal genes of some H3N2 AIVs were 
closely related to HPAI H5 AIVs, which may suggest reassortment with $\mathrm{H} 5 \mathrm{~N} 1, \mathrm{H} 5 \mathrm{~N} 2, \mathrm{H} 5 \mathrm{~N} 3, \mathrm{H} 5 \mathrm{~N} 6$, and H5N8 subtype AIVs $(8,32,34,40)$.

\section{H3N8 Subtype AIV}

Molecular epidemiological analysis revealed that the H3N8 subtype AIVs had complex sources. Studies have shown that the HA gene of H3N8 subtype AIV might come from the $\mathrm{H} 3$ subtype AIV that is prevalent in poultry in East Asia, Southeast Asia, and Europe (41-42), and the NA gene might come from East Asia, North America, and Europe (43-44). The NA gene of H3N8 subtype AIV could be divided into Eurasian lineage and North American lineage (45). The Eurasian lineage was widely detected in the whole country, while the North American lineage was mainly detected in eastern China $(8,11,45)$, indicating that gene reassortments have occurred between AIVs from the Eurasian lineage and the North American lineage $(8,45-47)$. These events most likely occurred in LPMs and could be transmitted from ducks to chickens (48). The internal genes of $\mathrm{H} 3 \mathrm{~N} 8$ AIVs were derived from a variety of AIVs from wild birds or domestic ducks $(24,49-50)$, including HPAI H5 viruses $(28,43,51-52)$.

The H3N8 subtype AIVs might be potential gene sources of AIVs causing interspecies transmission. During 2004-2005, researchers detected an H3N8 virus in domestic ducks in Beijing LPMs, of which HA gene was highly similar to the $\mathrm{H} 3 \mathrm{~N} 8$ virus that caused the 1989-1990 outbreaks in equine populations in northern China (43). In 2018, researchers found that the NA gene of the $\mathrm{H} 3 \mathrm{~N} 8$ virus isolated from a Guangdong LPM was highly homologous to H10N8 AIV and speculated that the N8 gene originated from the same lineage that caused human infections in 2014 (48).

\section{Other H3 Subtypes AIV}

Except for the AIVs of H3N2 and H3N8 subtypes, other AIVs of $\mathrm{H} 3$ subtypes were scattered in various regions of China (Figure 1) and had a high degree of genetic diversity and origin. A study indicated that the H5N1 subtype AIV in domestic ducks in Anhui Province and Fujian Province might be involved in the gene reassortment of H3N1 subtype AIV (53). The internal genes of $\mathrm{H} 3 \mathrm{~N} 3$ might be derived from viruses of waterfowl origin (mainly ducks) in North America (Alaska) and East Asia (Japan and the Republic of Korea) $(21-23,39)$. The HA gene of H3N5 detected in wild birds in Khanka Lake was closely related to poultry-origin AIVs isolated from southern China (21). Studies have shown that H3N6 frequently reassorted with $\mathrm{H} 5 \mathrm{~N} 6$ subtype AIVs (18,54-55), while PB2 and NP genes were also derived from H9N2 AIV that circulated in the same period (23). Experimental results showed that the novel H3N6 reassortant could effectively replicate in mammalian cells (54). The gene of H3N7 subtype AIV came from a variety of LPAIVs and had greater antigenic differences compared with the $\mathrm{H} 3$ subtype AIV strains isolated from previous studies (56).

\section{MAMMALIAN ADAPTIONS OF H3 SUBTYPE AIV}

In 1968, a novel H3N2 subtype virus contained genes from human-derived H2N2 influenza virus and avian-derived $\mathrm{H} 3$ subtype influenza virus was firstly reported in Hong Kong SAR and caused the pandemic globally (12). It highlighted the pandemic potential of $\mathrm{H} 3$ subtype AIVs. Mutations that increased replicative ability and transmissibility of the virus in mammals may facilitate the interspecies transmission (57-59). Previous studies have experimentally demonstrated the relation between some molecular mutations and receptor binding, transmission, replication, pathogenicity, and drug resistance of the $\mathrm{H} 3$ subtype AIV in mammals. Here, we have summarized the mammalian adaptation molecular markers in Table 1.

Receptor binding is the initial process of virus life circle. AIVs usually show higher binding preference for $\alpha 2,3$-Gal sialic acid receptors (avian-type), and increased binding capacity of $\alpha 2,6-\mathrm{Gal}$ sialic acid receptors (human-type) indicates increased adaptability in mammals. Studies have shown that $\mathrm{H} 3 \mathrm{~N} 2$ and H3N8 subtype AIVs could simultaneously bind to both avian-type and human-type receptors $(17,22,60)$. Overall, 2 residues, 226 and 228, of HA of the $\mathrm{H} 3$ subtype were well known to be important for the host range restriction (61). Recently, researchers found that residue $155 \mathrm{~T}$ in the HA protein could enhance the ability of H3N2 subtype AIV to bind to human-type receptors, and the virus could replicate effectively in the lungs and turbinates of mice (9). The G225D mutation of HA could increase the thermal stability of H3N2 AIV, which could probably lead to increased virus replication on Madin-Darby canine kidney (MDCK) cells (7). The H3N2 subtype AIV with Q226R and G228S mutations in HA could enhance the replicative ability and mammalian adaptability in 
TABLE 1. Key amino acid substitutions of H3 subtype avian influenza viruses associated with mammalian adaptation and their biological effects.

\begin{tabular}{|c|c|c|c|c|}
\hline Protein & Subtype & Mutation & Biological effects & References \\
\hline \multirow{3}{*}{ PB2 } & \multirow{3}{*}{ H3N8 } & K574E & $\begin{array}{l}\text { Decreased replicative ability in ferrets and transmission ability in mice, decreased } \\
\text { RNA polymerase activity in } 293 \mathrm{~T} \text { cells }\end{array}$ & $(69)$ \\
\hline & & T588A & $\begin{array}{l}\text { Decreased replicative ability in ferrets and transmission ability in mice, decreased } \\
\text { RNA polymerase activity in } 293 \mathrm{~T} \text { cells }\end{array}$ & $(69)$ \\
\hline & & $\mathrm{E} 627 \mathrm{~K}, \mathrm{D} 701 \mathrm{~N}$ & $\begin{array}{l}\text { Increased replicative ability on mammalian cells and transmission ability among } \\
\text { mammals }\end{array}$ & $(51)$ \\
\hline PB1 & H3N8 & S524G & $\begin{array}{l}\text { Enhanced RNA polymerase activity in human cells and MDCK cells, increased } \\
\text { replicative ability and pathogenicity in mice, enhanced airborne transmissibility } \\
\text { between ferrets }\end{array}$ & $(45)$ \\
\hline \multirow{4}{*}{$\mathrm{HA}$} & \multirow{3}{*}{$\mathrm{H} 3 \mathrm{~N} 2$} & G225D & Increased HA thermostability and replicative ability on MDCK cells & $(7)$ \\
\hline & & Q226R & Increased replicative ability and virulence in ferrets & $(17)$ \\
\hline & & G228S & Increased replicative ability and virulence in ferrets & $(17)$ \\
\hline & H3N8 & $155 T$ & Increased binding capacity of human $\alpha 2,6-\mathrm{Gal}$ sialic acid receptors & (9) \\
\hline \multirow{2}{*}{ NA } & H3N6 & D198N & $\begin{array}{c}\text { Increased probability of drug resistance, which might reduce the sensitivity of NA } \\
\text { inhibitor drugs (such as oseltamivir) }\end{array}$ & $(53,70)$ \\
\hline & H3N8 & G119P & $\begin{array}{l}\text { Increased probability of drug resistance, which might reduce the sensitivity of NA } \\
\text { inhibitor drugs (such as oseltamivir) }\end{array}$ & $(28,70)$ \\
\hline \multirow{2}{*}{ M1 } & \multirow{2}{*}{ H3N8 } & N30D & Increased pathogenicity in mice & $(51)$ \\
\hline & & T215A & Increased pathogenicity in mice & $(51)$ \\
\hline \multirow{2}{*}{ M2 } & \multirow{2}{*}{$\mathrm{H} 3 \mathrm{~N} 2$} & V27I & Reduce the sensitivity to M2 ion channel blockers (amantadine) & $(11)$ \\
\hline & & S31N & Reduce the sensitivity to M2 ion channel blockers (amantadine) & $(8,11,32,71)$ \\
\hline \multirow{2}{*}{ NS1 } & \multirow{2}{*}{$\mathrm{H} 3 \mathrm{~N} 2$} & D92E & $\begin{array}{l}\text { Increase probability of viral resistance to interferon, and further experimental } \\
\text { verification is needed }\end{array}$ & $(67,72)$ \\
\hline & & P42S & Increased replicative ability and virulence in mice & (7) \\
\hline
\end{tabular}

Abbreviation: MDCK=Madin-Darby canine kidney.

ferrets (17). The Q226L mutation of HA could promote the airborne transmission of the $\mathrm{H} 3 \mathrm{~N} 8$ virus in ferrets (45).

The RNA polymerase of the influenza virus is composed of three subunits including PB2, PB1, and PA proteins, which are related to the virus's hostspecificity and replication. Dong et al. found that $\mathrm{E} 627 \mathrm{~K}$ and $\mathrm{D} 701 \mathrm{~N}$ mutations in the $\mathrm{PB} 2$ protein of H3N8 AIV (51) might enhance the adaptability of the virus in mammalian cells and enable AIV to replicate efficiently in mammals (62-65). Another study found that the PB1 S524G mutation of wild bird-origin H3N8 virus could enhance the virulence and fitness for transmission in mammals (45).

Mutations that increase pathogenicity were also found. The N30D and T215A mutations found in the M1 protein could increase the pathogenicity of the H3N8 subtype AIV in mice (51). The residue at 42 of the NS1 protein in the H3N2 subtype AIV changed from $\mathrm{P}$ to $\mathrm{S}$, which might increase virus replication and virulence in mice $(7)$.

For drug resistance, the D198N and G119P mutations of NA protein have been identified in the natural isolates of $\mathrm{H} 3 \mathrm{~N} 6$ and $\mathrm{H} 3 \mathrm{~N} 8$, respectively. These mutations were likely to cause the $\mathrm{H} 3$ subtype
AIV with reduced sensitivity of NA inhibitors $(28,53)$. In addition, many studies have found that the V27I and $\mathrm{S} 31 \mathrm{~N}$ mutations of the matrix protein $(\mathrm{M})$ of H3N2 subtype AIV caused the virus to be resistant to amantadine $(8,11,18,32)$.

\section{DISCUSSION}

The $\mathrm{H} 3$ subtype AIVs have continuously circulated in wild birds and poultry in the mainland of China. Wild bird migration and live poultry trade play important roles for virus transmission. Frequent gene reassortments were observed between viruses from poultry and wild birds $(52,55-66)$, which increased the genetic diversity of $\mathrm{H} 3 \mathrm{AIVs}$ and contributed genes to other subtype AIVs such as HPAIV H5 (67-68). Despite the relatively improved surveillance studies having been performed in recent years in China, our understanding of the $\mathrm{H} 3$ AIVs transmission and evolution is still limited, especially in intercontinental migratory birds. The $\mathrm{H} 3$ viruses could acquire mammalian adaptation mutations during replication. Considering the pandemic history and the potential threat to public health, a long-term systematic 
surveillance of $\mathrm{H} 3 \mathrm{AIV}$ is imperative.

Funding: The National Natural Science Foundation of China (No: 81961128002).

\author{
doi: $10.46234 / \mathrm{ccdcw} 2021.225$ \\ \# Corresponding author: Yuelong Shu, shuylong@mail.sysu.edu.cn.
}

\begin{abstract}
${ }^{1}$ School of Public Health (Shenzhen), Shenzhen Campus of Sun Yatsen University, Shenzhen, Guangdong, China; ${ }^{2}$ Chinese National Influenza Center, National Institute for Viral Disease Control and Prevention, Chinese Center for Disease Control and Prevention, Beijing, China.
\end{abstract}

Submitted: October 09, 2021; Accepted: October 27, 2021

\section{REFERENCES}

1. Eisfeld AJ, Neumann G, Kawaoka Y. At the centre: influenza A virus ribonucleoproteins. Nat Rev Microbiol 2015;13(1):28 - 41. http://dx. doi.org/10.1038/nrmicro3367.

2. Webster RG, Bean WJ, Gorman OT, Chambers TM, Kawaoka Y. Evolution and ecology of influenza A viruses. Microbiol Rev 1992;56(1):152 - 79. http://dx.doi.org/10.1128/mr.56.1.152-179.

3. Fouchier RAM, Munster V, Wallensten A, Bestebroer TM, Herfst S, Smith D, et al. Characterization of a novel influenza A virus hemagglutinin subtype (H16) obtained from black-headed gulls. J Virol 2005;79(5):2814 - 22. http://dx.doi.org/10.1128/JVI.79.5.2814-2822. 2005.

4. Tong SX, Zhu XY, Li Y, Shi M, Zhang J, Bourgeois M, et al. New world bats harbor diverse influenza A viruses. PLoS Pathog 2013;9(10):e1003657. http://dx.doi.org/10.1371/journal.ppat.1003 657.

5. Mahy BWJ, Brown CC. Emerging zoonoses: crossing the species barrier. Rev Sci Tech 2000;19(1):33 - 40. http://dx.doi.org/10.20506/ rst.19.1.1212.

6. Bean WJ, Schell M, Katz J, Kawaoka Y, Naeve C, Gorman O, et al. Evolution of the $\mathrm{H} 3$ influenza virus hemagglutinin from human and nonhuman hosts. J Virol 1992;66(2):1129 - 38. http://dx.doi.org/10. 1128/jvi.66.2.1129-1138.1992.

7. Cai TY. Epidemiological analysis and biological characterization of $\mathrm{H} 3$ subtype avian influenza virus in Eastern China from 2017 to 2019. Yangzhou: Yangzhou University; 2020. http://dx.doi.org/10.27441/ d.cnki.gyzdu.2020.000350. (In Chinese).

8. Cui HR, Shi Y, Ruan T, Li XS, Teng QY, Chen HJ, et al. Phylogenetic analysis and pathogenicity of $\mathrm{H} 3$ subtype avian influenza viruses isolated from live poultry markets in China. Sci Rep 2016;6:27360. http://dx.doi.org/10.1038/srep27360.

9. Li C, Yu M, Liu LT, Sun HL. Characterization of a novel H3N2 influenza virus isolated from domestic ducks in China. Virus Genes 2016;52(4):568 - 72. http://dx.doi.org/10.1007/s11262-016-1323-0.

10. Liu S, Ji K, Chen JM, Tai D, Jiang WM, Hou GY, et al. Panorama phylogenetic diversity and distribution of type A influenza virus. PLoS One 2009;4(3):e5022. http://dx.doi.org/10.1371/journal.pone.000 5022.

11. Zou SM, Tang J, Zhang Y, Liu LJ, Li XY, Meng Y, et al. Molecular characterization of $\mathrm{H} 3$ subtype avian influenza viruses based on poultryrelated environmental surveillance in China between 2014 and 2017. Virology 2020;542:8 - 19. http://dx.doi.org/10.1016/j.virol.2020.01. 003 .

12. Cockburn WC, Delon PJ, Ferreira W. Origin and progress of the 196869 Hong Kong influenza epidemic. Bull World Health Organ 1969;41(3):345-8. https://pubmed.ncbi.nlm.nih.gov/5309437/.

13. Zhang YP, Zhao CH, Hou YJ, Chen Y, Meng F, Zhuang YC, et al. Pandemic threat posed by H3N2 avian influenza virus. Sci Chin Life Sci 2021;64:1984 - 7. http://dx.doi.org/10.1007/s11427-021-1916-4.

14. Guo YJ, Gao SQ, Wang YX, Zhang ZQ, Meng FY, Wang M, et al.
Isolation from wild ducks influenza group of viruses: two type A viruses with new hemagglutinin. Acta Microbiol Sin 1981;21(2):166 - 3. http:/ /dx.doi.org/10.13343/j.cnki.wsxb.1981.02.006. (In Chinese).

15. Chan PKS. Outbreak of avian influenza $\mathrm{A}(\mathrm{H} 5 \mathrm{~N} 1)$ virus infection in Hong Kong in 1997. Clin Infect Dis 2002;34 Suppl 2:S58-64. http://dx. doi.org/10.1086/338820.

16. Pepin KM, Wang J, Webb CT, Smith GJD, Poss M, Hudson PJ, et al. Multiannual patterns of influenza A transmission in Chinese live bird market systems. Influenza Other Respir Viruses 2013;7(1):97 - 107. http://dx.doi.org/10.1111/j.1750-2659.2012.00354.x.

17. Guan LZ, Shi JZ, Kong XT, Ma SJ, Zhang YP, Yin X, et al. H3N2 avian influenza viruses detected in live poultry markets in China bind to human-type receptors and transmit in guinea pigs and ferrets. Emerg Microbes Infect 2019;8(1):1280 - 90. http://dx.doi.org/10.1080/ 22221751.2019.1660590.

18. Jiao $M$, Liu XQ, Chen $T$, Zhang $H$, Fu WJ, Xie $Y$, et al. Epidemiological and phylogenetic analysis of $\mathrm{H} 3$ subtypes avian influenza viruses isolate from Poyang lake region, China, 2014-2017. Chin J Virol 2018;34(1):1-8. https://d.wanfangdata.com.cn/ periodical/bdxb201801001. (In Chinese).

19. Qiu BF, Liu WJ, Peng DX, Hu SL, Liu XF. Distribution of avian influenza virus subtypes among domestic ducks in eastern China. Acta Microbiol Sin 2008;48(10):1290 - 4. http://dx.doi.org/10.3321/j.issn: 0001-6209.2008.10.003. (In Chinese).

20. Sun J. Study on temporal and spatial relationship between bar-headed goose and avian influenza virus on Qinghai-Tibet plateau. Harbin: Northeast Forestry University. 2020. http://dx.doi.org/10.27009/ d.cnki.gdblu.2020.000068. (In Chinese).

21. Li X. Surveillance and evolution analysis of avian influenza virus in wild birds in Khanka Lake, Heilongjiang, 2013-2018. Harbin: Northeast Forestry University. 2019. http://dx.doi.org/10.27009/d.cnki. gdblu.2019.000332. (In Chinese).

22. Guan LJ. Characterization of $\mathrm{H} 3$ subtype avian influenza virus in China from 2009 to 2013. Harbin: Northeast Forestry University; 2014. http://dx.doi.org/10.7666/d.Y2620838. (In Chinese).

23. Liu M, He SQ, Walker D, Zhou NN, Perez DR, Mo B, et al. The influenza virus gene pool in a poultry market in South Central China. Virology 2003;305(2):267 - 75. http://dx.doi.org/10.1006/viro.2002. 1762.

24. Liu TT, Xie ZX, Song DG, Luo SS, Xie LJ, Li M, et al. Genetic characterization of a natural reassortant $\mathrm{H} 3 \mathrm{~N} 8$ avian influenza virus isolated from domestic geese in Guangxi, Southern China. Genome Announc 2014;2(4):e00747 - 14. http://dx.doi.org/10.1128/genomeA. 00747-14.

25. Hu JK, Zha YF, Jin XJ, Wen XH, Li ZX, Wang X, et al. Continuous adaptation of the $\mathrm{HA}$ and $\mathrm{NA}$ gene of $\mathrm{H} 3 \mathrm{~N} 2$ subtypes of avian influenza virus in South China, 2017-2018. J Infect 2019;79(1):61 74. http://dx.doi.org/10.1016/j.jinf.2019.01.009.

26. Tang L, Tang WJ, Li XF, Hu CX, Wu D, Wang TH, et al. Avian influenza virus prevalence and subtype diversity in wild birds in Shanghai, China, 2016-2018. Viruses 2020;12(9):1031. http://dx. doi.org/10.3390/v12091031.

27. Yang XY. Surveillance of wild bird influenza combined with sentinels in Hubei Province. Harbin: Northeast Forestry University. 2020. http://dx.doi.org/10.27009/d.cnki.gdblu.2020.000661. (In Chinese).

28. Wang C, Fei RM. Genome sequencing and genetic analysis of H3N8 subtype avian influenza virus isolated from mallard. Chin Vet Sci 2016;46(12):1489 - 96. http://dx.doi.org/10.16656/j.issn.1673-4696. 2016.12.003. (In Chinese).

29. Tian HY, Zhou S, Dong L, Van Boeckel TP, Cui YJ, Newman SH, et al. Correction for Tian et al. , Avian influenza H5N1 viral and bird migration networks in Asia. Proc Natl Acad Sci USA 2015;112 (22):E2980.

30. Zeng XW, Hua YP, Li XB, Zhang ZM. Monitoring Influenza A virus and Newcastle disease virus in migratory waterfowls in Sanjiang natural reserve of Heilongjiang Province. Acta Microbiol Sin 2008;48(10): 1403 - 7. http://dx.doi.org/10.3321/j.issn:0001-6209.2008.10.023. (In Chinese). 
31. Peng Y, Xie ZX, Liu JB, Pang YS, Deng XW, Xie ZQ, et al. Epidemiological surveillance of low pathogenic avian influenza virus (LPAIV) from poultry in Guangxi Province, Southern China. PLoS One 2013;8(10):e77132. http://dx.doi.org/10.1371/journal.pone.007 7132.

32. Yang DQ, Liu J, Ju HB, Ge FF, Wang J, Li X, et al. Genetic analysis of H3N2 avian influenza viruses isolated from live poultry markets and poultry slaughterhouses in Shanghai, China in 2013. Virus Genes 2015;51(1):25 - 32. http://dx.doi.org/10.1007/s11262-015-1198-5.

33. Liu TT, Xie ZX, Song DG, Luo SS, Xie LJ, Deng XW, et al. Whole genome sequencing and analysis of eleven strains of avian influenza virus subtype $\mathrm{H} 3 \mathrm{~N} 2$ isolated in Guangxi province. Chin J Vet Sci 2017;37(5):859 - 65. http://dx.doi.org/10.16303/j.cnki.1005-4545. 2017.05.18. (In Chinese).

34. Li QH, Zhao QQ, Gu M, Zhu J, Gu XB, Zhao G, et al. Genome sequence of a novel reassortant $\mathrm{H} 3 \mathrm{~N} 2$ avian influenza virus from domestic mallard ducks in Eastern China. Genome Announc 2013;1(2):e0022112. http://dx.doi.org/10.1128/genomeA.00221-12.

35. Li J, Liu F, Liu DF, Luo Q, Li YJ, Liu CG. Isolation, identification and sequence analysis of a $\mathrm{H} 3 \mathrm{~N} 2$ subtype influenza virus originated from wild duck. Mod J Anim Husb Vet Med 2015(8):1 - 6. http://dx. doi.org/10.3969/j.issn.1672-9692.2015.08.001. (In Chinese).

36. Zhao G, Zhong L, Zhao KK, Lu XL, Peng DX, Liu XF. Isolation and characterization of $\mathrm{H} 3 \mathrm{~N} 2$ influenza viruses from ducks. Acta Vet Zootech Sin 2010;41(10):1354-8. https://d.wanfangdata.com.cn/ periodical/ChlQZXJpb2RpY2FsQ0hJTmV3UzIwMjExMDI2Eg94bX N5eGIyMDEwMTAwMjMaCDdvNjl2aDRl. (In Chinese).

37. Deng GH, Tan D, Shi JZ, Cui PF, Jiang YP, Liu LL, et al. Complex reassortment of multiple subtypes of avian influenza viruses in domestic ducks at the Dongting Lake Region of China. J Virol 2013;87(17): 9452 - 62. http://dx.doi.org/10.1128/JVI.00776-13.

38. Hu T. Full-length genes sequence and pathogenicity analysis of two $\mathrm{H} 3 \mathrm{~N} 2$ avian influenza viruses isolate from ducks [dissertation]. Changchun: Jilin Agricultural University; 2013. http://cdmd.cnki. com.cn/Article/CDMD-10193-1013309621.htm. (In Chinese).

39. Wu HB, Wu NP, Peng XR, Jin CZ, Lu XY, Cheng LF, et al. Molecular characterization and phylogenetic analysis of $\mathrm{H} 3$ subtype avian influenza viruses isolated from domestic ducks in Zhejiang Province in China. Virus Genes 2014;49(1):80 - 8. http://dx.doi.org/10.1007/ s11262-014-1065-9.

40. Li CR, Bai R, Deng JL, Che RF, Liang D, Zhao W, et al. Reassortant $\mathrm{H} 3 \mathrm{~N} 2$ avian influenza virus isolated outside live poultry markets in Guangdong province. J Pathog Biol 2020;15(6):685 - 91,697. http:// dx.doi.org/10.13350/j.cjpb.200613. (In Chinese).

41. Cui HR. Phylogenetic analysis and pathogenicity of $\mathrm{H} 3$ subtype avian influenza viruses isolated in live poultry market of southern China. Beijing: Chinese Academy of Agricultural Sciences; 2016. http://cdmd.cnki.com.cn/Article/CDMD-82101-1016169857.htm. (In Chinese).

42. Cui PF, Lu KP, Chen S, Xiao L, Guan LZ, Deng GH, et al. Biological characteristic of two H3N8 subtype avian influenza viruses (AIV). J Agric Biotechnol 2016;24(7):980-6. http://www.cnki.com.cn/ Article/CJFDTotal-NYSB201607005.htm. (In Chinese).

43. Pu J, Liu QF, Xia YJ, Fan YL, Brown EG, Tian FL, et al. Genetic analysis of $\mathrm{H} 3$ subtype influenza viruses isolated from domestic ducks in northern China during 2004-2005. Virus Genes 2009;38(1):136 - 42. http://dx.doi.org/10.1007/s11262-008-0300-7.

44. Wang YL. HA and NA genes phylogenic analysis of AIV isolates from wild birds and the distribution/transmission pattern of AIV in wild birds. Harbin: Northeast Forestry University; 2009. http://cdmd. cnki.com.cn/Article/CDMD-10225-2009132374.htm. (In Chinese).

45. Zhang XH, Li YG, Jin S, Zhang YM, Sun LY, Hu XY, et al. PB1 S524G mutation of wild bird-origin H3N8 influenza A virus enhances virulence and fitness for transmission in mammals. Emerg Microbes Infect 2021;10(1):1038 - 51. http://dx.doi.org/10.1080/22221751. 2021.1912644

46. Cheng SJ, Li JP, Hou GY, Peng C, Wang SC, Jiang WM, et al. Whole genome sequence analysis of 14 strains of $\mathrm{H} 3$ subtype avian influenza virus. Chin J Vet Med 2018;54(10):30-5. https://kns.cnki.net/ KCMS/detail/detail.aspx?dbcode=CJFD\&filename $=$ ZSYZ201810007.

47. Zhao T. Epidemiological surveilence study on avian influenza virus and its infection risk [dissertation]. Beijing: Academy of Military Sciences; 2018. http://cdmd.cnki.com.cn/Article/CDMD-90101-1018094574. htm. (In Chinese).

48. Li X, Chen JL, Jin XJ, Hu JK, Xie SM, Dai YX, et al. Characterization of three $\mathrm{H} 3 \mathrm{~N} 2$ and one new reassortant $\mathrm{H} 3 \mathrm{~N} 8$ avian influenza virus in South China. Infect Genet Evol 2019;75:104016. http://dx.doi.org/ 10.1016/j.meegid.2019.104016.

49. Wu HB, Yang F, Liu FM, Peng XM, Chen B, Cheng LF, et al. Molecular characterization of H10 subtype avian influenza viruses isolated from poultry in Eastern China. Arch Virol 2019;164(1):159 79. http://dx.doi.org/10.1007/s00705-018-4019-z.

50. Wu HB, Peng XM, Peng XR, Wu NP. Molecular characterization of a reassortant H11N9 subtype avian influenza virus isolated from a domestic duck in Eastern China. Arch Virol 2015;160(10):2595 - 601. http://dx.doi.org/10.1007/s00705-015-2528-6.

51. Dong BB, Xu CL, Dong LB, Cheng HJ, Yang L, Zou SM, et al. A novel reassortant $\mathrm{H} 3 \mathrm{~N} 8$ influenza virus isolated from drinking water for duck in a domestic duck farm in Poyang Lake area. Biomed Environ Sci 2013;26(7):546 - 51. http://dx.doi.org/10.3967/0895-3988.2013.07. 005.

52. Crawford PC, Dubovi EJ, Castleman WL, Stephenson I, Gibbs EP, Chen LM, et al. Transmission of equine influenza virus to dogs. Science 2005;310(5747):482 - 5. http://dx.doi.org/10.1126/science.1117950.

53. Guan LZ, Wang J, Lu KP, Zhang F, Xiao L, Cui PF, et al. Biological characteristics of two H3N1 subtype avian influenza viruses (AIV). J Agric Biotechnol 2017;25(7):1162-9. https://d.wanfangdata.com.cn/ periodical/nyswjsxb201707014. (In Chinese).

54. Li XY, Yang JY, Liu B, Jia YN, Guo J, Gao X, et al. Co-circulation of $\mathrm{H} 5 \mathrm{~N} 6, \mathrm{H} 3 \mathrm{~N} 2, \mathrm{H} 3 \mathrm{~N} 8$ and emergence of novel reassortant H3N6 in a local community in Hunan province in China. Sci Rep 2016;6:25549. http://dx.doi.org/10.1038/srep25549.

55. Li RY, Zhang T, Xu J, Chang JX, Xu B. Isolation of two novel reassortant $\mathrm{H} 3 \mathrm{~N} 6$ avian influenza viruses from long-distance migratory birds in Jiangxi Province, China. Microbiologyopen 2020;9(8):e1060. http://dx.doi.org/10.1002/mbo3.1060.

56. Gu WL, Cui PF, Cui JQ, Han SY, Xing X, Deng GH, et al. The complete genomic sequence and infectivity analysis of a H3N7 subtype avian influenza virus. Chin J Prev Vet Med 2017;40(7):565-8, 574. https://d.wanfangdata.com.cn/periodical/ChlQZXJpb2RpY2FsQ0hJT mV3UzIwMjExMDI2EhF6Z3lmc314YjIwMTgwNzAwMRoIcW9saH kyMjU\%3D. (In Chinese).

57. Herfst S, Schrauwen Eefje J, Linster M, Linster M, Chutinimitkul S, de Wit E, et al. Airborne transmission of influenza $\mathrm{A} / \mathrm{H} 5 \mathrm{~N} 1$ virus between ferrets. Science 2012;336(6088):1534 - 41. http://dx.doi.org/10.1126/ science. 1213362

58. Wan HQ, Perez DR. Amino acid 226 in the hemagglutinin of H9N2 influenza viruses determines cell tropism and replication in human airway epithelial cells. J Virol 2007;81(10):5181 - 91. http://dx. doi.org/10.1128/JVI.02827-06.

59. Wang D, Yang L, Gao R, Zhang X, Tan Y, Wu A, et al. Genetic tuning of the novel avian influenza $\mathrm{A}(\mathrm{H} 7 \mathrm{~N}$ 9) virus during interspecies transmission, China, 2013. Euro Surveill 2014;19(25):20836. http://dx. doi.org/10.2807/1560-7917.es2014.19.25.20836.

60. Guan LZ. Biological characterization of H3N2 (from 2009 to 2014) and H5 (from 2015 to 2016) avian influenza viruses in China. Lanzhou: Gansu Agricultural University. 2017. http://cdmd.cnki. com.cn/Article/CDMD-10733-1017824803.htm. (In Chinese).

61. Galvan G. Hypothalamic peptide hormones. Acta Med Austriaca 1978;5(3):55-61. https://pubmed.ncbi.nlm.nih.gov/110023/.

62. Hatta M, Gao P, Halfmann P, Kawaoka Y. Molecular basis for high virulence of Hong Kong H5N1 influenza A viruses. Science 2001;293(5536):1840 - 2. http://dx.doi.org/10.1126/science.1062882.

63. Subbarao EK, London W, Murphy BR. A single amino acid in the PB2 gene of influenza A virus is a determinant of host range. J Virol 1993;67(4):1761 - 4. http://dx.doi.org/10.1128/jvi.67.4.1761-1764. 
1993.

64. Zhang LS, Zhang ZG, Weng ZP. Rapid reassortment of internal genes in avian influenza $A(H 7 N 9)$ virus. Clin Infect Dis 2013;57(7):1059 61. http://dx.doi.org/10.1093/cid/cit414.

65. Yu ZJ, Sun WY, Zhang XH, Cheng KH, Zhao CQ, Gao YW, et al. Multiple amino acid substitutions involved in the virulence enhancement of an $\mathrm{H} 3 \mathrm{~N} 2$ avian influenza A virus isolated from wild waterfowl in mice. Vet Microbiol 2017;207:36 - 43. http://dx.doi.org/ 10.1016/j.vetmic.2017.05.020

66. Yang SY. Surveillance of influenza virus in wild birds in Qin Huangdao in Hebei and Xianghai in Jilin. Harbin: Northeast Forestry University. 2015. http://cdmd.cnki.com.cn/article/cdmd-10225-1015655577.htm. (In Chinese).

67. Hu CX, Li XF, Zhu CH, Zhou F, Tang WJ, Wu D, et al. Cocirculation of multiple reassortant $\mathrm{H} 6$ subtype avian influenza viruses in wild birds in eastern China, 2016-2017. Virol J 2020;17(1):62. http:// dx.doi.org/10.1186/s12985-020-01331-z.

68. Zhang Y, Chen MM, Huang YW, Zhu WF, Yang L, Gao LD, et al. Human infections with novel reassortant $\mathrm{H} 5 \mathrm{~N} 6$ avian influenza viruses in China. Emerg Microbes Infect 2017;6(6):e50. http://dx.doi.org/ 10.1038/emi.2017.38

69. Cui PF. Biological characterization of $\mathrm{H} 3 \mathrm{~N} 8$ avian influenza viruses isolated from 2009 to 2013 in China. Lanzhou: Gansu Agricultural University; 2016. http://cdmd.cnki.com.cn/Article/CDMD-107331016902421.htm. (In Chinese).

70. Richard M, Deléage C, Barthélémy M, Lin YP, Hay A, Lina B, et al. Impact of influenza A virus neuraminidase mutations on the stability, activity, and sensibility of the neuraminidase to neuraminidase inhibitors. J Clin Virol 2008;41(1):20 - 4. http://dx.doi.org/10.1016/ j.jcv.2007.10.021.

71. Choi JG, Kang HM, Kim MC, Paek MR, Kim HR, Kim BS, et al. Genetic relationship of $\mathrm{H} 3$ subtype avian influenza viruses isolated from domestic ducks and wild birds in Korea and their pathogenic potential in chickens and ducks. Vet Microbiol 2012;155(2 - 4):147 - 57. http:// dx.doi.org/10.1016/j.vetmic.2011.08.028.

72. Li WZ, Wang GF, Zhang H, Xin G, Zhang DG, Zeng J, et al. Effects of NS1 variants of $\mathrm{H} 5 \mathrm{~N} 1$ influenza virus on interferon induction, TNF $\alpha$ response and p53 activity. Cell Mol Immunol 2010;7(3):235 42. http://dx.doi.org/10.1038/cmi.2010.6 